International Journal of Linguistics, Literature and Translation

ISSN: 2617-0299 (Online); ISSN: 2708-0099 (Print)

DOI: $10.32996 /$ ijllt

Journal Homepage: www.al-kindipublisher.com/index.php/ijltt

IJLLT

\title{
A Pragma-Stylistics Analysis of Lowell and Snodgrass' Confessional Poems
}

\author{
Widad Almas Barakhas ${ }^{\mathbf{1}} \square$ and Prof. Sarab Khlil, PhD ${ }^{2}$ \\ 'Student, MA in Linguistics, English Department, College of Arts, Baghdad University, Iraq \\ ${ }^{2}$ English Department, College of Arts, Baghdad University, Iraq \\ $\square$ Corresponding Author: Widad Almas Barakhas, E-mail: wabrakhas1967@yahoo.com
}

\section{ARTICLE INFORMATION}

Received: 14 October 2021

Accepted: 14 November 2021

Published: 30 November 2021

DOI: $10.32996 /$ ijllt.2021.4.11.18

\section{KEYWORDS}

Pragmatics stylistics, confessional poetry, speech act, Grice's maxims, deixis.

\section{ABSTRACT}

Analyzing any text according to pragmatic principles means approaching the text's meaning and the writer's intention. This study investigates the role of pragmatics theories in interpreting and understanding poetic text and their impact on the poet's style. In other words, how the poets exploit pragmatics theories, such as Searle's speech acts, Grice's maxims, and deixis, in their style of writing to convey their intended meaning to the readers. Therefore, two confessional poems are selected to be analyzed pragma-stylistically: The Dolphin was written by Robert Lowell (1973), and Mementos 1 was written by W. D. Snodgrass (1960s). The current study aims to: 1) analyze the texts of selected poems by applying pragmatics theories to find out the style of each poet through which one can reach the right interpretation of the poem.2) find out the most dominant type of speech acts used by each poet. 3) investigate any flouting of Grice's maxims. 4) identify types of deixis and find out the most dominant types used in confessional poems. The present study concludes that 1) representative speech acts are performed more than other types.2) most of Grice's maxims are flouted, and the quantity maxim is the most dominant flouted by each poet. 3) Both poets use person deixis more than other types.

\section{Introduction}

Confessional poetry is a style of poetry that emerged in the United States during the late 1950s and lasted through the late 1960s. The most well-known poets associated with this poetic genre are Robert Lowell, W.D.Snodgrass, John Berryman, Anne Sexton, and Sylvia Plath, whose confessional works mark a turning point in the history of American poetry. It is described as poetry of the personal or of the 'I' that sheds light on particular experiences and emotions about death, trauma, depression, sexuality, and relationship. It is frequently addressed in an autobiographical manner.

This study provides a pragma-stylistics analysis of two selected confessional poems composed by two pioneers: W.D. Snodgrass (1926-2009), and Robert Lowell (1917-1977).

In this study, the researcher will investigate how pragmatics theories such as speech act, Grice's cooperative principle and maxims, and deixis are stylistically exploited and applied in poetic texts.

As for the application of speech act in poetry, this study focuses on the stylistic effects of speech acts theory in conveying the poet's intended meaning and the theme of his poems.

As for the application of implicatures, this study will focus on how stylistic devices such as metaphor, irony, simile, repetition, ellipsis, etc., are employed in flouting the cooperative principle and its four maxims to generate implicatures. In addition to speech acts theory and Grice's maxims, this study will also investigate how deixis plays a role in interpreting the meaning of the poetic text.

Copyright: (c) 2021 the Author(s). This article is an open access article distributed under the terms and conditions of the Creative Commons Attribution (CC-BY) 4.0 license (https://creativecommons.org/licenses/by/4.0/). Published by Al-Kindi Centre for Research and Development, London, United Kingdom. 
Although many studies investigate the pragma-stylistics analysis of literary genres like novels, plays, songs, and so on, no detailed pragma-stylistic analysis of confessional poetry has been carried out to highlight the individual characteristics of language use. The present study tries to fill a gap in this respect with the help of the theoretical framework of Searle (1979) for analyzing speech acts, Grice (1975) for flouting the maxims, and Alan Cruse (2000) to analyze types of deixis.

\section{Pragmatics stylistics}

Pragmatics stylistics or pragma-stylistics is one of the stylistics branches that emerged in the sixties but became an important approach during the eighties and nineties. It is an integration of approaches of pragmatics and stylistics. Both Hickey (1993: 578) and Davies (2007:106) agree that pragma-stylistics is stylistic with adding pragmatics components. It is the application of pragmatics concepts to the analysis and interpretation of literary texts. The pragma-stylistic approach to meaning is a linguistic one that focuses on the speaker's intended meaning and his/ her distinctive style. Specific modes of speech are thought to be unique and therefore include characteristics that distinguish them from others. According to Leech (1981:5), the pragmatic study of language aims to explore the meaning derived from the context in which the utterance is used and how it is used rather than from the formal properties of words and constructions (as in semantics). Pragmatics is described as a theory of appropriateness in this definition.

In its most basic form, stylistics is described by Babajide (2000:123) as "the study of style." He also acknowledges Davy and Crystal's (1983) concept that "style is the effectiveness of a mode of expression". As a result, we can claim that stylistics is the theory of effectiveness, while pragmatics is the theory of appropriateness.

Black (2006: 2) states that "Since pragmatics is known as the study of language, it is understandable that stylistics has become increasingly interested in using the insights it can offer". According to Nørgaard et al. (2010: 4), the goals of stylistics are to describe the style of specific authors, genres, or texts, and to qualify analysts' intuitions about the texts as well as to make them aware of 'linguistic' features and patterns of the language in general. On the other hand, pragmatics aims to show how the users of language obtain sentences to express their intentions that are not directly expressed by the propositional content of the sentences. For Bex et al. (2010:37), pragmatics supports stylistics as its domain expands and provides it with new devices to investigate those effects or meanings. Huang (2007:19), as other scholars, defines pragma- stylistics as the application of theoretical pragmatics findings and methodologies to the study of style in language. As a result, pragma-stylistics, as a stylistic study based on pragmatic principles, aims to discover, analyze, and formalize the intended meaning of an utterance.

\section{Pragmatics theories \\ 3.1 Speech Acts (SAs)}

People typically use utterances that include grammatical and substantive structures and words to express themselves, but they often use those utterances to perform actions. Those actions that are performed by utterances are called speech acts. According to Yule (1996:47), people use language to communicate activities such as requesting information, giving instructions, conveying information, making threats, giving alerts, making requests, etc.

Austin (a British philosopher) first presented the SAs concept in 1954 in his lectures at Oxford University. Then, in 1955, It was delivered by William James in his lectures at Harvard University, which later on published under How to do things with words as mentioned by (Huang, 2007: P.93). Austin presents SAs theory as a reaction to previous linguistic views and theories that ignored language's functional aspects. Austin (1962:6) distinguishes between two kinds of utterances: performative acts that perform actions and constative propositions that can be true or false. For the performance of the utterances to be successful, Austin proposes certain conditions called felicity conditions. Those conditions state:

1-There should exist an accepted conventional procedure having a specific conventional effect.

2- A particular speech act must be performed by an appropriate person, at an appropriate time, and place.

3-The procedure must be performed by all participants both wholly and correctly. If any condition is violated, the speech act will be infelicitous (ibid.: 14-15).

He (ibid.: 99) states that in issuing an utterance, three acts can be produced at the same time: the locutionary act (the act of uttering words), the illocutionary act (the act which has a certain force by uttering words), and the perlocutionary act (the effects of the speaker's utterance on the hearer).

Austin classified SAs into Verdictives, Excercitives, Commissives, Behabitives, and Expositives. 
Later on, Searle (1969) adapted and developed Austin's Speech Acts theory in his leading book "Speech Act" (Verschueren, 1999:22). He develops felicity conditions into four: preparatory conditions, sincerity conditions, propositional conditions, and essential conditions. According to Cutting (2002: 16-17), Searle classifies SAs into five categories:

1- Representatives SAs state what the speaker believes to be the case, like describing, insisting, asserting, predicting, etc.

2- Commisives are words that commit the speaker to future action like a promise, offer, threaten, refuse, etc.

3- Directives are acts in which the speaker gets the listener to do something like a command, request, suggest, etc.

4- Expressives include acts in which the words express the speaker's psychological state like an apology, regret, congratulate, etc.

5- Declaratives are words and expressions that immediately change the institutional state of an affair like bet, declare, resign, etc.

\subsection{The Cooperative Principle (CP)}

In 1967, the theory of cooperative principle was formulated by Paul Grice and delivered in William James lectures at Harvard. Then, in 1975, it was published in his article Logic and Conversation. Grice (1975: 45) states, "make your conversational contribution such as required, at the stage at which it occurs, by the accepted purpose or direction of the talk exchange in which you are engaged". He (ibid.:46) states that four sub-principles called maxims should be followed to comply with this principle. Those four maxims are:

1. The Maxim of Quantity: Make your contribution as informative as is required, not more or less informative than is required.

2. The Maxim of Quality: Make your true contribution one, do not say what you believe to be false and do not say that for which you lack adequate evidence.

3- The Maxim of Relation: Make your contribution relevant. Be relevant.

4. The Maxim of Manner: Avoid obscurity of expression. Avoid ambiguity. Be brief and orderly.

Grice's cooperative principle and its maxims can be observed or not in any conversation. The non-observance of the maxims can occur in five ways: flouting, violating, suspending, opting out, and infringing. This study will focus on flouting the maxims which may occur, according to Thomas (1995:65), when a speaker blatantly fails to observe a maxim at a level of what is said with the deliberate intentions of generating an implicature. The flouting in poetry can occur when the poet conveys his message indirectly by using figures of speech like metaphor, irony, overstatements, understatements, ellipsis, repetition, etc.

\subsection{Deixis}

According to Yule (1969:9), deixis is a Greek term that means "pointing via language," and any linguistic form used to achieve this pointing is called indexical (deictic expression). Levinson (1983:54) states that deixis means "pointing or indicating". The interpretation of deictic expression depends on the speaker and the listener who share the same context in face-to-face interaction. Two basic terms differentiate deictic expressions: proximal (near the speaker) like (here, now, this), and distal (away from the speaker) like (there, then, that). There are three types of deixis, according to Yule (1996): person, place, and time deixis. Whereas, according to Archer et al. (2012: 27), Levinson (1983) categorizes deixis into five types as illustrated below:

\section{1- Person deixis}

It includes the first person (the speaker), second person (the addressee), and third person (neither the speaker nor the addressee). According to Cruse (2006:127), person deixis includes personal pronouns (l, you, he, she, him, yourself, myself, etc.), and possessive adjectives like (my, her, his).

\section{2- Spatial deixis}

A spatial deictic word denotes a position or location in relation to the speaker. The spatial deictic expressions include adverbs (here, there), verbs of motion (come, go), demonstratives (that, those, this), and specific locations (in, on).

\section{3- Temporal deixis}

It refers to the time of the speaker's utterance. The temporal deictic expressions include adverbs (now, then), demonstrative expressions (next year, this month), verb tenses (past, present, future).

\section{4- Social deixis}

It encodes the relationship between the speaker, the addressee, and the others. There are two types of social deixis, according to Levinson (1983): absolute expressions like (Mr./ Mrs./ Miss), and relational expressions like kinship terms which are determined by the relationship between the speaker, the addressee, and bystander. (Archer et al., 2012: 27).

5- Discourse deixis

It refers to a prior or upcoming part of the discourse. For instance, "Besides, she is a good driver", here "besides" refers to a prior part of the discourse (ibid.). 


\section{The Methodology \\ 4.1 The Model of Analysis}

In this study, Lowell and Snodgrass' poems are analyzed pragma-stylistically according to an eclectic model, including Searle's speech acts (1979), Grice's cooperative principle, and maxim (1975), and Cruse (2006) for deixis. Hence, for the analysis of each poem, Searle's classification of SAs, including representative, expressive, directive, commissive, and declaration are investigated. Besides, Grice's maxims, including quality, quantity, manner, and relation, are investigated in each poem to show to what extent both poets exploited and flouted them to convey their intended meaning to their readers. Five types of deixis, including (person, spatial, temporal, social, discourse) have been analyzed to show to what extent they are affected in the interpretation of each poem. It is worth mentioning that this study follows a mixed-method (quantitative and qualitative) in analyzing the data. The quantitative approach provides numerical data for the current study to characterize, explain, predict, or monitor a phenomenon under study. The qualitative analysis will then be carried out depending on the numerical data.

\subsection{The Data}

The data that is analyzed in the current study includes two confessional poems: one written by Robert Lowell entitled The Dolphin (1973), the other belongs to Snodgrass entitled Mementos 1 (the 1960s).

\section{The Analysis}

\subsection{The Dolphin (1973)}

M y Dolphin, you only guide me by surprise, ................1

A captive as Racine, the man of craft, .............................2

Drawn through his maze of iron composition ................3

By the incomparable wandering voice of Phedre. ........4

When I was troubled in mind, you made for my body ..5

Caught in its hangman's-knot of sinking lines,...............6

The glassy bowing and scraping of my will ....................7

I have sat and listened to too many ..................................8

Words of the collaborating muse, .....................................

And plotted perhaps too freely with my life, ...............10

Not avoiding injury to others, .........................................11

Not avoiding injury to myself- .........................................12

To ask compassion ..... this book, half fiction, ................13

An eelnet made by man for the eel fighting ....................14

My eyes have seen what my hand did. ..............................15

This sonnet is a flashback of Lowell's life. It is concerned with love that makes freedom meaningful. The poet focuses on his past life and how he had no control over his life which was led by surprise. The poet's ex-wife, "Caroline Blackwood, "is the image of love in this poem, and she is referred to as the Dolphin and mermaid. The Dolphin's love brings him to the ground and saves his life.

\subsubsection{Speech Acts}

In this poem, only three types of SAs are performed to achieve different functions and reflect different meanings. The total number of speech acts is (11) as shown in table (1):

Table (1): Statistical distributions of SAs in The Dolphin

\begin{tabular}{|l|l|l|}
\hline Types of SAs & Frequency & Percentage \\
\hline Representative SA & 4 & $36.36 \%$ \\
\hline Commisive SA & 0 & $0 \%$ \\
\hline Declarative SA & 0 & $0 \%$ \\
\hline Expressive SA & 6 & $54.54 \%$ \\
\hline Directive SA & 1 & $9.10 \%$ \\
\hline Total & 11 & $100 \%$ \\
\hline
\end{tabular}

Quantitatively, the above Table shows that expressive speech acts are the most dominant used (6) times, i.e. (54.54\% ). Expressive speech acts serve the functions of regretting (3) times, confessing twice, and praising once, whereas representative speech acts are in the second position with (4) times realization, i.e. (36.36\%) and serve the functions of describing twice, and each of stating 
and comparing once. A directive speech act is in the third position with one realization, i.e. (9.10\%), and serves the function of asking, whereas both commissive and declaration speech acts state in the last position without any realization.

Qualitatively, line 1 carries an expressive SA of praising. Here Lowell refers to a woman (most likely his wife Caroline Blackwood) who he loves. He calls her Dolphin. He praises her for how she saves him from his previous life, which led by surprise, and he hadn't any control over it. Line 5 carries an expressive SA of confessing when the poet confesses that he had got mental troubles due to his usual manic depression, for which he had been hospitalized many times. Another expressive act of confessing appears obviously in line7 "The glassy bowing and scraping of my will". Here the word "glassy" often points to having no vitality or expression in a man's eyes. In this line, Lowell confesses that he feels as if everything is emotionally taken out of him and therefore has no will to live. Lines 8- 12 also carry two expressive speech acts but of regret. Lowell expresses his disappointment and regrets that he had spent so much time listening to others than just to himself. This regretting continues in lines 11 and 12 , in which Lowell expresses his disappointment that he didn't plan his early life and he spent it too freely by not avoiding injuring others or even himself. This could reflect his carelessness. Here the word "injury" is repeated to emphasize his feeling of resentment. Lowell concludes the poem with another expressive speech act of regretting "my eyes have seen what my hand did,". This last line refers to his conscience. It reflects his regret when he remembers his previous life and discovers things and actions he did wrong and was responsible for during his early life.

The first example of representative speech acts is in line 2, which carries a speech act of comparing when Lowell compares his captivity under a manic depression and uncontrolled life to Jean Baptiste Racine's style "the French dramatist in seventeenthcentury" of writing his tragedy "Phèdre". Lowell's favorite writer is Racine, and expressions like 'man of craft' and 'iron composition' refer to his invention and usage of the dodecasyllabic (12 syllable meter) and his complex craft. Lowell knows that he did many wrong things, but he couldn't change them, just like the characters in Racine's tragedy. Line 6 carries two representative speech acts. The first is of stating when the poet states that his wife "the Dolphin" helped him physically thru the time when he was sick and unable to help himself. The second is of describing when the poet describes his body as "a hangman's knot of sinking line". A hangman's knot is associated with suicide, and a sinking line refers to a weighty thing or heavier than water. When these two phrases come together, they reflect the image of Lowell's mental suffering, and thus physical deteriorating, then having his wife assist him physically and lift him from the bottom of the water. Line 14 carries another representative speech act of describing. The poet describes his struggling with himself as an eel captured in a net.

Line 13 is an example of a directive speech act of asking "to ask compassion . . this book, half fiction". Here Lowell asks those around him to pity him. Even though their pity may not be true, maybe because they don't believe or realize it is true.

\subsubsection{Flouting Grice's Maxims}

It is noticed, in this poem, that the poet flouts Grice's maxims (15) times, as shown in Table (2) below:

Table(2): The statistical distribution of flouting Grice's maxims in The Dolphin

\begin{tabular}{|l|l|l|}
\hline Types of maxims & Number of Flouts & Percentage \\
\hline Quality & 4 & $26.67 \%$ \\
\hline Quantity & 10 & $66.67 \%$ \\
\hline Relation & 0 & $0 \%$ \\
\hline Manner & 1 & $6.66 \%$ \\
\hline Total & $\mathbf{1 5}$ & $\mathbf{1 0 0} \%$ \\
\hline
\end{tabular}

Quantitatively, Table (2) shows that flouting quantity maxim is in the first position with (10) times usage, i.e. (66.67\%). The maxim of quantity is flouted when more or less information is presented by using ellipsis words or phrases (9) times, and repetition once. Flouting a quality maxim is in the second position with (4) times usage, i.e. (26.67\%), which occurred by using metaphor (3) times, and simile once. In the third position is flouting manner maxim with only one usage, i.e. (6.66\%), which occurred by using ambiguous and unclear expressions. The maxim of relation is not flouted in this poem so that it states in the last position.

Qualitatively, the maxim of quantity is broken when the poet uses more or less information than is required by repeating the phrase "not avoiding injury to" in lines 11 and 12 to implicate Lowell's carelessness in his previous life and emphasize his disappointment. The maxim is also flouted by ellipsis words such as ellipsis of the subject "I" and its verb "was" in line 2; ellipsis of the relative clause "who was" in line 3; ellipsis of the subject "I" and the verb "have" in line 10; ellipsis of the subject "I" and the verb "was" in lines 11 and 12. 
As for flouting the quality maxim, there is a metaphoric expression in line 1 represented by the item "Dolphin" in "My Dolphin, you only guide me by surprise". The Dolphin is a metaphor for a woman who stands with him and pulls him up from his uncontrolled past life with his previous wife to a new world full of love and hope. This metaphor flouts the maxim of quality with the implicature that the Dolphin shows Lowell's love of the world in the form of his wife.

In lines 2-4, "A captive as Racine, the man of craft,/Drawn through his maze of iron composition/ By the incomparable wandering voice of Phedre", Lowell compares his captivity under manic depression and his uncontrolled past life with Jean Baptiste Racine "the French dramatist in the seventeenth century" and his tragedy "Phèdre". The simile in these lines flouts the maxim with the implicature that Lowell knows he did many wrong things previously, but he could not change them just like the characters in Racine's tragedy Phaedra and his restriction with a complex style of writing by using dodecasyllabic.

The metaphoric expression "a hangman's knot of sinking line" in line 6 again flouts the maxim. This line is a metaphor of suicide with the implicature that he was thrown, like a fisherman's knot, in the depths of the water.

Line 14, "An eelnet made by man for the eel fighting" is a metaphor that flouts the maxim of quality with the implication that the poet personifies an eel's struggle in an eelnet to his own struggling with mental illness.

Manner maxim is flouted when the poet uses unclear and ambiguous expressions in line 13 when he says, "To ask compassion ..... this book, half fiction", this book is a metaphor to his pomes which he refers to them as half fiction, but it is unclear what the second half is?

\subsubsection{Deixis}

In this poem, all types of deixis are realized, and the total number is (24) as shown in Table 3 below:

Table (3): The statistical distribution of Types of Deixis in The Dolphin

\begin{tabular}{|l|l|l|}
\hline Types of deixis & Frequency & Percentage \\
\hline Person & 13 & $54.17 \%$ \\
\hline Spatial & 1 & $4.17 \%$ \\
\hline Temporal & 7 & $29.16 \%$ \\
\hline Discoursal & 2 & $8.33 \%$ \\
\hline Social & 1 & $4.17 \%$ \\
\hline Total & $\mathbf{2 4}$ & $\mathbf{1 0 0} \%$ \\
\hline
\end{tabular}

Quantitatively, table 3 shows that person deixis is frequently used (13) times, i.e. (54.17\%), followed in sequence by temporal deixis (7) times, i.e. (29.16\%), discourse deixis twice, i.e. (8.33\%), and each of spatial and social deixis once, i.e. (4.17\%).

Qualitatively, person deixis is encoded by first-person pronouns (I, me, my), second-person pronoun (you), third-person pronoun (his), and a reflective pronoun (myself) as illustrated below:

In lines 1 and 5, an anaphoric deictic expression "you" refers to the antecedent "The Dolphin"; while the deictic expression "me" refers to Lowell himself. In line 3, the deictic expression "his" refers to the style of writing of the French dramatist in the seventeenth century called "Jean Baptiste Racine". In lines 5 and 8, the first-person pronoun "I" refers to the poet himself, while the possessive pronoun "my", in the whole poem, refers to the poet's possessive things like Dolphin, body, will, life, eyes, and hand. In line (12), the reflective pronoun "myself" refers to the speaker (the poet) himself.

Temporal Deixis is encoded by using time deictic expression (when), and verb tenses (past, past perfect, present, present perfect) as illustrated below:

In line 5, the time deictic expression "when" refers to the period when the poet was mentally troubled and was always hospitalized. Throughout the poem, the poet uses past tenses (made, plotted, did) and past perfect tenses (was troubled) to refer to distal events in his life, and uses present tense (guide) and present perfect tenses (have sat, have seen) to refer to the time of the speaker's utterance.

On the other hand, there are some expressions in this poem function as discoursal deixis, for instance: the deictic expression "and" is used in line10 to emphasize the idea of the prior segment of discourse (the poet's carelessness in his past life) and this idea continues in upcoming discourse. In line13, the proximal demonstrative expression "this" is used as discourse deixis to refer to upcoming discourse and as a place deictic expression to refer to Lowell's poems. 
Finally, Lowell calls his wife with a multiple name "Dolphin," which functions as social deixis and illustrates the close relationship between the poet and his new wife.

\subsection{Mementos 1 (1960)}

S1- Sorting out letters and piles of my old

Canceled checks, old clippings, and yellow note cards

That meant something once, I happened to find

Your picture. That picture. I stopped there cold,

Like a man raking piles of dead leaves in his yard

Who has turned up a severed hand?

S2- Still, that first second, I was glad: you stand

Just as you stood-shy, delicate, slender,

In that long gown of green lace netting and daisies

That you wore to our first dance. The sight of you stunned

Us all. Well, our needs were different, then,

And our ideas came easy.

S3- Then through the war and those two long years

Overseas, the Japanese dead in their shacks

Among dishes, dolls, and lost shoes; I carried

This glimpse of you, there, to choke down my fear,

Prove it had been, that it might come back.

That was before we got married.

S4 -Before we drained out one another's force

With lies, self-denial, unspoken regret

And the sick eyes that blame; before the divorce

And the treachery. Say it: before we met. Still,

I put back your picture. Someday, in due course, I will find that it's still there.

Memory is the central theme of this poem, as is the ability of mementos, like a photograph, to reawaken past emotions and memories. The poet looks through a series of old papers, including "Canceled checks, old clippings, and yellow note cards", and suddenly he shocks when he finds a photograph of his first wife, but then he feels happy for a moment. The photograph was taken in their first dance in which she seemed to be very young and attractive. He recalls how the photograph had helped him cope with his anxiety during the war, but he is bitter as he recalls their failed marriage and divorce.

\subsubsection{Speech Acts}

In this poem, the total number of speech acts is (17) as shown in Table (4):

Table (4): The statistical distributions of SAs in Mementos 1

\begin{tabular}{|l|l|l|}
\hline Types of SAs & Frequency & Percentage \\
\hline Representative SAs & 14 & $82.35 \%$ \\
\hline Commisive SAs & 0 & $0 \%$ \\
\hline Declarative SAs & 0 & $0 \%$ \\
\hline Expressive SAs & 3 & $17.65 \%$ \\
\hline Directive SAs & 0 & $0 \%$ \\
\hline Total & 17 & $100 \%$ \\
\hline
\end{tabular}

Quantitatively, Table 4 shows that only two types of speech acts are realized in this poem: Representatives and expressive, whereas commissive, declarative, and directive speech acts are never realized. Representative speech acts are in the first position with (14) times occurrence, i.e. (82.35\%), and serve the functions of describing (5) times, remembering (3) times, each comparing and asserting twice, and each telling and stating once. Expressive speech acts are in the second position with (3) times occurrence, i.e. (17.65\%), and serve the functions of expressing feelings twice, and regretting once.

Qualitatively, the first representative SA of describing is performed in the first three lines when the poet described his old things when he was sorting up through his old papers like old checks which the bank has been paid and returned, as well as pieces of old newspapers and magazines that he was interested in at the time, and note cards that have yellowed with age. Then, stanza 2 
carries another two representative speech acts of describing when the poet describes his ex-wife in the photo taken in that time. She looked innocent, pretty, slim, shy, and very attractive in her green dress, and he describes themselves as idealistic and optimistic about their beliefs and life goals. The fourth instance of representative speech acts of describing is in stanza 3 when he describes his two years at war as long and how that time was unhappy and difficult. He describes the horrors of the war for the soldiers and for ordinary Japanese people who were dead in their cottages among their "dishes, dolls, and lost shoes". Then in stanza 4, the poet describes how their regretting appeared in their eyes but remained unspoken, how their eyes reflected their blaming each other for reaching the end of their marriage. The first instance of representative speech acts of remembering is performed in stanza 2 when the poet remembers taking a photograph in his first meeting and dancing with his ex-wife. Stanza 3 carries a second representative speech act of remembering when the poet recalls how this photo helped him cope with his anxiety during his two years at war. Stanza 4 also carries a third representative speech act of remembering when the poet remembers the breaking down of his marriage which ended in divorce. Representative SAs of comparing is first performed in stanza one lines 5 and 6, "Like a man raking piles of dead leaves in his yard Who has turned up a severed hand" when the poet compares his shock of seeing the photograph to the shock of a man who finds a severed hand among the dead leaves as he is tidying his garden. Stanza 4 line 1 carries another representative speech act of comparing when the poet compares their way of sapping each other's passion for life to the draining of water from a vessel which is left empty, and their life was emptied of joy and happiness like a drained vessel. A representative speech act of state is performed in the last two lines in stanza 2 when the poet states that their needs were simple when they were young and had simpler expectations of life and each other. The poet asserts that a quick looking at her photo at that horror time removed his fear and made him hope that he could find that happy time again. So, it is a representative speech act of asserting. He asserts that her photo comforted him before they got married. In the last two lines, the poet tells and addresses his wife and asserts that he still keeps her photo to look at someday. So it is a representative speech act of telling as well as of asserting.

The first instance of the expressive speech act of expressing feeling is performed in stanza 1, Line 3, "Your picture. That picture. I stopped there cold," when the poet feels shocked when he first sees his ex-wife's photograph. Stanza 2 Line 1 carries a second expressive speech act of expressing feeling when the poet feels happy for a moment after his first shocking of seeing her photo because the photo brings him back to a happy memory. Stanza 4 lines 2-3 carries a third expressive speech act but of regretting when the poet feels sorry and regrets because they drained each other "with lies and self-denial", and they both regretted, but they did not tell each other, and their regrets remained unspoken.

\subsubsection{Flouting the Maxims}

In this poem, the poet flouts Grice's maxims (10) times, as shown in Table (5) below:

Table (5): The statistical distribution of Grice's maxims flouting in Mementos 1

\begin{tabular}{|l|l|l|}
\hline Types of maxims & Number of Flouts & Percentage \\
\hline Quality & 4 & $40 \%$ \\
\hline Quantity & 5 & $50 \%$ \\
\hline Relation & 0 & $0 \%$ \\
\hline Manner & 1 & $10 \%$ \\
\hline Total & $\mathbf{1 0}$ & $\mathbf{1 0 0} \%$ \\
\hline
\end{tabular}

Quantitatively, the above Table shows that three types of maxims are flouted in this poem: quality, quantity, and manner, whereas the relation maxim is not flouted. The most dominant flouting has occurred in quantity maxim (5) times, i.e. (50\%), followed by the quality maxim (4) times flouting, i.e. (40\%), and the manner maxim is flouted once (10\%).

Qualitatively, the quantity maxim is flouted when the poet is more or less informative than is required by using repetition and ellipsis of some words or phrases. In stanza 1, the poet flouts the maxim when he repeats the word "picture" in "Your picture. That picture. I stopped there cold" with the implicature that the poet wants to emphasize that the photo of someone, who was once very significant to him, is unique for him and he knows it. The maxim is also flouted by repeating the word "piles" in lines 1 and 5 , the word "still" in stanza 2 and 4 is repeated three times as well as the word "before" is repeated four times in stanzas 3 and 4 with the implicature that the poet wants to emphasize that the photo was taken when they met first. They were innocent and loved each other before their marriage and before their divorce. The maxim is also flouted by using ellipsis when the poet omits the clause "when I have been" at the beginning of line 1 Stanza 1.

The quality maxim is flouted when the speaker's utterance is not true or has no adequate evidence. In poetry, the maxim is flouted when the poet uses irony, metaphor, simile, personification, etc. In this poem, Snodgrass flouts the maxim when he uses simile in 
stanza 1, "Like a man raking piles of dead leaves in his yard Who has turned up a severed hand." in which he compares his shock of seeing his ex-wife's picture to a man who suddenly finds a severed hand when he is "raking piles of dead leaves in his garden".

Then, in stanza 3, the maxim is also flouted by using the metaphor "choke" in "to choke down my fear" when he looked at her photo when he was in the war, as something comforts him but choking something down implicates the opposite that is not relaxing and a comfortable task. Another flouting by metaphor occurred in stanza 4 when the poet says, "Before we drained out one another's force". Here the poet compares their draining each other to the draining of the bath or vessel from water and left empty just like their life emptied of happiness and passions. A third metaphor, "sick eyes" in "And the sick eyes that blame" is flouted the maxim with the implicature that their eyes literary were not sick, but they reflected their feelings of dislike, anger, and blaming each other.

The manner maxim is flouted when the speaker utters something unclear or ambiguous and vague. In this poem, it is unclear why the poet keeps the photo to look at again someday rather than throwing it away. So the maxim is flouted with the implicature that despite painful memories of his marriage, the photo reminds him of a happy and loving time with his ex-wife.

\subsubsection{Deixis}

In this poem, all types of deixis are realized, and the total number is (74) as shown in Table (6) below:

Table (6): The statistical distribution of types of Deixis in Mementos 1

\begin{tabular}{|l|l|l|}
\hline Types of deixis & Frequency & Percentage \\
\hline Person & 27 & $36.49 \%$ \\
\hline Spatial & 15 & $20.27 \%$ \\
\hline Temporal & 9 & $12.16 \%$ \\
\hline Discoursal & 9 & $12.16 \%$ \\
\hline Social & 14 & $18.92 \%$ \\
\hline Total & $\mathbf{7 4}$ & $\mathbf{1 0 0} \%$ \\
\hline
\end{tabular}

Quantitatively, the above Table shows that person deixis is the most dominant used (27) times, i.e. (36.49\%) and it is represented by the first person deictic words (I, my, us, we, our), second-person deictic words (you, your), and third-person deictic words (it, their, his). Spatial deixis is in the second position with 15 times usage, i.e. (20.27\%), and it is represented by distal deictic word (that) which is the most dominant used five times, followed by (there) 3 times, (in and come) twice for each, and each of (among, those, this) once. Social deixis is present in the third position with (14) times usage, i.e. (18.92\%), and only represents by using personal pronouns like (you, your, our, we, us). Both temporal and discourse deixis is in the fourth position with (9) times usage, i.e. (12.16\%). Temporal deixis is represented by temporal deictic words (once, first, second, first, two long years, before, and someday). Whereas discourse deixis is represented by using deictic words like (that, still, this, then, and).

Qualitatively, throughout the poem, the first person pronoun (I) refers to the poet himself (the speaker). The possessive pronoun (my) refers to his belongs like "old Canceled checks, old clippings, and yellow note cards", whereas the second person pronoun (you) refers to the addressee (his ex-wife). Its possessive pronoun (your) refers to her belongings like a picture. Other person deictic words like; (we) refers to both of them (the poet and his ex-wife), and their possessive pronoun (our) refers to their belongs like (first dance, needs, ideals); third person possessive pronoun (his) refers to the man's yard in stanza 1; the object pronoun (us) refers to the poet and all the people when they were stunned by the sight of his ex-wife in their first meeting; (their) refers to the shacks of the Japanese people; and (it) refers to the picture of his ex-wife.

Spatial deixis is represented, in this poem, by distal deictic words (that, those, and there) which refer to places away from the speaker, proximal deictic word (this), which refers to a place near the speaker, projected word (come) which implies moving toward a certain location (toward the speaker), and specific location words (in, among).

The proximal deictic word (this), in Stanza 3, refers to the place of the photo near the speaker (the poet) which he looked at in the war, whereas the distal deictic word (that), in stanza 1, refers to the place of the picture away from the speaker when it was taken; in stanza 2 line 1(that) refers to an event happened in the past (away from the speaker's utterance)when he first met his ex-wife, and in line 3 refers to the long gown of his ex-wife; after that in stanza 3 line, 6 refers to the time when he was happy with her before their marriage. The distal deictic word (there), in stanza 1, refers to the place where the poet found his ex-wife's picture and was shocked for a moment, then in stanza 3 refers to the place where the poet spent two years in the war, and in stanza four refers to the place where the poet put back the photo to look at someday. The last distal deictic word the poet uses is (those), which refers to the long two years the poet spent away from his love in the war. Other spatial deictic words used in this poem are 
(in and among). (In) refers, in stanza 1, to a specific place (the yard of the man) and in stanza 3 to shocks of the Japanese people as well as (among) refers to the place of dead Japanese among their dishes, shoes, and dolls in their shocks. The project word (came) in stanza two refers to their ideals which came easy because of their simple needs when they were young, whereas in stanza three refers to the coming back of happiness to the poet's life after horrible years that he spent in the war.

Social deixis is only represented by using personal pronouns like (you, your, our, we, us), which indicate the social status between the poet and his ex-wife.

The poet uses the temporal deictic word (before) 4 times in stanzas 3 and 4 to refer to a specific time before their marriage, their draining each other, their divorce, and their meeting. (once) stanza 1 refers to the time when his old pieces were important and meant something to him a long time ago. (first second) in stanza two refers to the time when he found her picture and felt glad for a second, whereas (two long years) in stanza 3 refers to the time when he spent two years in the war. (someday) in stanza four refers to a time in the future. Throughout the poem, the poet uses past tenses like (stopped, came, wore, met) to refer to events that happened in the past away from the time of the speaker's utterance. At the end of the poem, the future tense (will) refers to someday in the future when he will look again at his ex-wife's picture.

Discourse Deixis is represented by deictic words (that, then, this, still, and). In stanza 1, lines 3 and 4, (that) refers to the previous portion of utterance to the poet's old things that meant something to him in a previous time, whereas line 4 refers to the picture of his ex-wife. In stanza 2, (that) refers to the previous second when the poet finds the picture, and in Stanza 3, it refers to the time when he was in the war before their marriage when looking at her photo, which comforted him. Another discourse deictic word is (then), which refers to the relation between previous discourse and an utterance. Then the deictic word (this) in stanza 3 refers to upcoming discourse, to his quick looking at his ex-wife in the war that comforted him. (still), in stanza 2, it refers to a prior utterance to the time when the poet is first shocked when he finds his ex-wife's picture, and then he feels happy for a moment. (and) in stanza 2 indicates the relationship between the prior discourse and upcoming utterance. It emphasizes the idea of their simple needs before marriage which made their ideas come easy.

\section{The Overall Results}

Table (7) below shows the overall results of analyzing speech acts in both poems "The Dolphin" and "Mementos 1".

Table (7): The overall results of types of speech acts in both poems

\begin{tabular}{|l|l|l|}
\hline Types of SAs & Frequency & Percentage \\
\hline Representative SAs & 18 & $64.29 \%$ \\
\hline Commisive SAs & 0 & $0 \%$ \\
\hline Declarative SAs & 0 & $0 \%$ \\
\hline Expressive SAs & 9 & $32.14 \%$ \\
\hline Directive SAs & 1 & $3.57 \%$ \\
\hline Total & 28 & $100 \%$ \\
\hline
\end{tabular}

After analyzing the types of speech acts in both poems, the results reveal that both poets perform speech acts (28) times. Representative speech acts are the most dominant performed (18) times i.e. (64.29\%), followed by expressive speech act with (9)times performance i.e. (32.14\%), directive speech acts with one performance, i.e. (3.57\%), whereas both commissive and declarative speech acts are never performed by both poets in their poems.

Table (8): The overall results of flouting Grice's maxims in both poems

\begin{tabular}{|l|l|l|}
\hline Types of maxims & Number of Flouts & Percentage \\
\hline Quality & 8 & $32 \%$ \\
\hline Quantity & 15 & $60 \%$ \\
\hline Relation & 0 & $0 \%$ \\
\hline Manner & 2 & $8 \%$ \\
\hline Total & $\mathbf{2 5}$ & $\mathbf{1 0 0} \%$ \\
\hline
\end{tabular}

Table (8) above shows that the total results of flouting Grice's maxims are (25). The highest flouting is occurred in quantity maxim (15) times i.e. (60\%), followed by the quality maxim, which is occurred (8) times i.e. (32\%), and the manner maxim, which is flouted twice i.e. (8\%). In contrast, the relation maxim is not flouted by both poets in their poems. 
Table (9): The overall results of using types of deixis in both poems

\begin{tabular}{|l|l|l|}
\hline Types of deixis & Frequency & Percentage \\
\hline Person & 50 & $46.30 \%$ \\
\hline Spatial & 16 & $14.81 \%$ \\
\hline Temporal & 16 & $14.81 \%$ \\
\hline Discoursal & 11 & $10.19 \%$ \\
\hline Social & 15 & $13.89 \%$ \\
\hline Total & $\mathbf{1 0 8}$ & $\mathbf{1 0 0} \%$ \\
\hline
\end{tabular}

Table (9) above shows that all types of deixis are used by both poets (108) times. Person deixis is the most dominant used (50) times i.e. (46.30\%), followed by both spatial and temporal deixis with (16) times usage for each i.e. $(14.81 \%)$, and social deixis with (15) times usage i.e. (13.89\%). In contrast, discourse deixis is in the last position with (11) times usage, i.e. (10.19\%).

\section{Conclusion}

The current study aimed at finding out the impact of pragmatics theories on the style of each poet as well as on interpreting his intended meaning; finding out the most dominant type of speech acts used by each poet; investigating any flouting of Grice's maxims; identifying types of deixis and finding out the most dominant types used in confessional poems.

Based on the results of the analysis, the following conclusions are obtained: First, using pragmatics theories and stylistic features such as (ellipsis, repetition, overstatements, understatements, irony, metaphor, simile, etc.) play a significant role in interpreting each poem's explicit and implicit meaning. Second, the results of analyzing Searle's speech act types in the selected poems reveal that both poets perform only three types: representative, expressive and directive speech acts, whereas both commisive and declarative speech acts are never performed. Third, both poets flout only three types of Grice's maxims in their poems. The highest flouting is occurred in the quantity maxim, followed by flouting the quality maxim and the manner maxim, whereas the relation maxim is never flouted. Fourth, both poets used all types of deixis. Person deixis is the most dominant used because confessional poems are autobiographical in which the poet confesses his problems to the readers.

The significance of the current study is that it presents a pragm-stylistic analysis of literary works such as poetry and specifically confessional poetry which is not examined before.

Further research is required to support this study by investigating the applicability of other pragmatic theories like presupposition, politeness, and impoliteness strategies to confessional poetry or other types of poetry.

Additionally, a contrastive study can be conducted between female and male confessional poets to explore how pragmatic theories are exploited in their style of writing and the differences and similarities between them?

\section{References}

[1] Archer, D., Aijmer, K., \& Wichmann, A. (2012). Pragmatics. An advanced resource book for students. New York: Routledge.

[2] Austin, J.L. (1962) How to Do Things with Words. $2^{\text {nd }}$ ed. Oxford: Oxford University Press.

[3] Bex, T., Burke, M. \& Stockwell, P. (2010).Contextualized Stylistics: In Honour of Peter Verdonk. Edinburgh: Edinburgh University Press.

[4] Black, E.(2006) Pragmatic stylistics. Edinburgh: Edinburgh University Press.

[5] Cruse, A. (2006). A Glossary of Semantics and Pragmatics. Edinburgh University Press Ltd 22 George Square, Edinburgh.

[6] Cutting, J. (2002). Pragmatics and Discourse. London: Routledge.

[7] Davies, W. A. (2007). An Introduction to Applied Linguistics. Edinburgh: Edinburgh University Press.

[8] Grice, H.P. (1975) "Logic and Conversation". In: Cole P. and Morgan, J. (eds.): Syntax and Semantics Vol. III: Speech Acts.New York: Academic Press. 4158.

[9] Hickey, L. (1993). Stylistics, Pragmatics, and Pragmastylistics. Revue Belge De Philology Et D'histoire, Vol. 71, No. 3, pp. 573586.https://doi.org/10.3406/rbph.1993.3890

[10] Huang, Y. (2007). Pragmatics. Oxford: Oxford University Press.

[11] Leech, G. (1983). Principles of Pragmatics. London: Longman.

[12] Levinson, S.C. (1983). Pragmatics. New York: Oxford University Press.

[13] Searle, J. (1979). Expression and Meaning: Studies in the Theory of Speech Acts. Cambridge: Cambridge University Press.

[14] Thomas, Jenny. (1995). Meaning in Interaction: An Introduction to Pragmatics. London: Longman.

[15] Verschueren, J. (1999) Understanding pragmatics. London: Arnold

[16] Yule, G. (1996) Pragmatics. Oxford: Oxford University Press.

\section{Online References}

[1] The Dolphin By: Robert Lowell by Christopher - Pr ezi

[2] the-dolphin-byrobert-lowel> https://prezi.com 
[3] Poem Analysis by Rita Hamdani on Prezi

[4] poem-analysis> mfhtryrnjzpf > https://prezi.com

[5] Mementos, 1 by W. D. Snodgrass/Poetry Foundation

[6] https://www.poetryfoundation.org > Poems

[7] Department of Basic Education 2015. Mind the Gap English First Additional Language: Paper 2 Literature Poetry Study Guide Grade English.pdf p.76-83 